Karolina Bielenin-Lenczowska

\title{
TRUDNE TEMATY, TRUDNE BADANIA. O WIELOSTANOWISKOWEJ ETNOGRAFII WŚRÓD MACEDOŃSKICH MUZUŁMANÓW (TORBESZÓW) W MACEDONII I WE WLOSZECH ${ }^{1}$
}

\begin{abstract}
WSTĘP
Antropologia kultury od ostatnich kilku dekad „zmierza się” z określeniem własnej tożsamości w obrębie nauk humanistycznych i społecznych. Rozmyciu uległy jej sztywne granice jako nauki, której celem miał być opis i analiza zjawisk kulturowych odległych, egzotycznych ludów. Prowadzimy badania w dużych miastach, transnarodowych korporacjach, w Internecie lub wśród członków własnej rodziny, a także analizujemy rozmaite dyskursy. I nie zajmujemy się jedynie tradycyjnymi dla naszej dyscypliny zagadnieniami, takimi jak pokrewieństwo, obrzędowość rodzinna i doroczna oraz magia. Również w związku z przemianami współczesnego świata „tubylcy” są znacznie bardziej mobilni niż byli dawniej, studiują antropologię, a wielu z nich wiedzie życie nieróżniące się od naszego. Z tym wszystkim wiążą się kłopoty natury teoretycznej, metodologicznej i etycznej. Są to m.in. dylematy, w jaki sposób określić granice i specyfikę naszej dyscypliny, jak przeformułować pewne definicje związane z rozumieniem wielu współczesnych zjawisk kulturowych lub jak poradzić sobie z kwestią anonimowości rozmówców, autorytetu etnograficznego i autorstwa tekstu antropologicznego.

Niniejszy tekst składa się z dwóch części. Pierwsza z nich porusza wybrane problemy metodologiczne i etyczne wynikające z prowadzenia badań terenowych w zachodniej Macedonii, druga - wynikająca w pewnej mierze z pierwszej - ma na celu przedstawienie dyskursu politycznego i naukowego związanego z macedońskojęzycznymi Muzułmanami (Torbeszami) w Macedonii: na czym polega kwestia wykorzystania wiedzy miejscowych naukowców i współpracy z nimi podczas opracowywania wyników badań.
\end{abstract}

* Dr, adiunkt, antropolożka i lingwistka, Instytut Etnologii i Antropologii Kulturowej, Uniwersytet Warszawski, ul. Żurawia 4, 00-503 Warszawa; k.bielenin@uw.edu.pl.

1 Tekst artykułu powstał w $2011 \mathrm{r}$. 


\section{METODOLOGICZNE I ETYCZNE PROBLEMY PROWADZENIA BADAŃ - OD TERENU DO TEKSTU}

Wiele już zostało powiedziane i napisane na temat statusu i biografii badacz$\mathrm{ki} /$ badacza $\mathrm{w}$ terenie, jak również tego, w jaki sposób wpływa to na proces badawczy (począwszy od samego terenu, skończywszy na analizie). Uważam jednak, że w zmieniających się realiach prowadzenia badań i definicji samego pojęcia terenu, kwestia ta nabiera nowych znaczeń i wywołuje wciąż nowe pytania. Dlatego też spróbuję - w kontekście mojego własnego doświadczenia terenowego - zdefiniować pojęcie „bycia w terenie” i umieścić w nim moje własne badawcze oraz prywatne zaangażowanie.

\section{POJĘCIE TERENU: BYĆ TAM I BYĆ TU}

Bronisław Malinowski jasno zdefiniował badania terenowe. W jego czasach etnografowie wiedzieli, kiedy jest się „tam”, a kiedy „tu”. Wiedzieli również, kiedy zaczynają się i kończą badania. Wiedzieli też, kogo należy badać. Mianowicie, zgodnie z zaleceniami Malinowskiego, należało odbyć daleką podróż do egzotycznej wsi (zakładał, że powinna to być niewielka społeczność złożona z ok. 400-500 członków), przebywać wśród jej mieszkańców co najmniej rok i studiować każdy detal ich życia i kultury w taki sposób, aby badacz mógł poznać wszystkich członków tej społeczności osobiście, nie zadowalał się ogólnymi informacjami. Wreszcie celem etnografa było zgłębienie szczegółu i opisanie go za pomocą tubylczej terminologii, a więc w języku miejscowym (Notes and Queries... 1912). Jak można się łatwo domyślić, nic z tych wyznaczników nie pozostało stabilne i pewne we współczesnej antropologii.

Obecnie pojęcie „terenu” jest rozumiane bardzo szeroko, mimo że nadal staramy się, aby badania terenowe były wyznacznikiem naszej dyscypliny i rodzajem obrzędu przejścia dla jej adeptów.

W inspirującej książce Constructing the field... pod redakcją Vered Amit, już sam tytuł wskazuje, że teren nie jest nam dany, ale to badacze go sobie konstruują. Jak pisze Karin Norman, jedna z autorek tej książki, mimo że jesteśmy zawsze gdzieś umiejscowieni (located), to pole naszych badań terenowych nie sprowadza się do miejsc, w których je prowadzimy. Tak samo, jak kultura nie sprowadza się do jakichś miejsc (N or m a n 2000: 137). Zwracają również na to uwagę Akhil Gupta i James Fergus on (2004: 273), gdy piszą o „,narodowym” lub „etnograficznym" nawyku, a więc o tendencji do łączenia ludzi - kultur, narodów - z konkretnymi miejscami. Poza tym, jak pisze dalej Norman, staliśmy się (antropolodzy) podobni do tych, których studiujemy: migrantów, uchodźców. Mianowicie staliśmy się translokalni - zarówno etnograficznie, jak i teoretycznie. Ma to swoje oczywiste konsekwencje w tym, jak postrzegamy i prowadzimy badania terenowe (N orman 2000: 139). 
Terenem może być zatem wszystko. Jak zauważa Katarzyna K a n i o w s k a (1999: 74), jest on przede wszystkim „swoistą przestrzenią doświadczenia badacza". To nie tylko egzotyczna, odległa wioska, w której mieszkają zupełnie odmienni od nas ludzie. Jest to również nasz dom²: miasto, kraj, firma, organizacja lub nawet własna rodzina. Ponadto w naszym domu możemy znaleźć tych klasycznych tubylców, którzy przyjechali do „krajów Zachodu”. Co więcej, ci tubylcy również coraz częściej studiują antropologię lub przynajmniej czytają etnograficzne teksty. Nie mamy już zatem monopolu na wiedzę o jakichś ludziach, musimy być bardziej ostrożni w formułowaniu wniosków - oni bowiem mogą to przeczytać lub chcieć poddać autoryzacji przygotowany już tekst.

Moje badania wydają się z gruntu klasyczne - aby znaleźć się w terenie (w Macedonii lub we Włoszech) muszę tam pojechać; doświadczam zamieszkiwania w obcym dla siebie miejscu, posługuję się obcym językiem/językami oraz stykam się z odmiennymi dla mnie praktykami - żywieniowymi, religijnymi itd. Niemniej jednak w dzisiejszym świecie nie jest łatwo oddzielić teren od domu. Mianowicie, będąc tam, mam możliwość nie tylko stałego kontaktowania się z bliskimi w Polsce, ale również - co istotniejsze z metodologicznego punktu widzenia - mam możliwość rozmów z kolegami i koleżankami z pracy lub innymi naukowcami. A zatem mogę na bieżąco analizować zebrany materiał. Jest to oczywiście korzystne dla całości procesu badawczego, choć uczciwie należy wykazać, kto i w jakiej sytuacji mi pomógł (np. umieszczając w tekście podziękowania konkretnym osobom). Będąc w terenie, dzięki użyciu nowych technologii komunikacyjnych (Sarah Pink nazywa to ,etnografią elektroniczną”; P in k 2000: 107), mogę również na bieżąco umawiać się z rozmówcami na spotkania nieformalne lub dopytywać.

$\mathrm{Z}$ kolei będąc $\mathbf{w}$ domu, mam stały kontakt $\mathrm{z}$ wieloma rozmówcami, którzy stali się moimi znajomymi na Facebooku lub z którymi rozmawiam przez Skype'a. A zatem również to, że początek badań terenowych wiąże się z przyjazdem etnografa w teren, a koniec z jego wyjazdem, przestało być jakąkolwiek cechą definiującą. Jak to trafnie, ale dobitnie, wyraziła Sarah P i n k (2000: 107): „Kwestia tego, czy lub kiedy prowadziłam badania była jedynie pozornie rozwiązana poprzez przyznawane mi finansowanie". Ponadto zaciera się granica pomiędzy życiem prywatnym i zawodowym. Pink doświadczyła tego szczególnie, ponieważ jej głównym rozmówcą był jej własny mąż, którego „przywiozła” z ,terenu” w Hiszpanii. Również Virginia C a p u to (2000: 28), która prowadziła badania w mieście, w którym mieszkała i pracowała w tamtym czasie, zauważa, że: „Jedną z trudności charakteryzujących badania prowadzone w pobliżu domu (home) jest to, że nie można być całkowicie «w terenie» ani nie można cał-

2 „Dom” rozumiem w tym tekście szeroko, jak angielskie home; może ono oznaczać zarówno mój własny dom, jak i miasto bądź kraj, w którym żyję. 
kowicie «opuścić terenu»". Wydaje się, że stwierdzenie to dotyczy nie tylko tych, którzy uprawiają antropologię we wlasnym domu, ale także tych, którzy wyjeżdżają w teren stosunkowo daleko od domu. Zakładam bowiem, że obecnie nie ma większej różnicy pomiędzy tym, gdzie fizycznie znajduje się nasz teren, ponieważ dzięki dostępowi do nowych technologii komunikacyjnych oraz mobilności „tubylców”, jesteśmy w stanie być jednocześnie w wielu miejscach. Poza tym terenem jest przede wszystkim analizowany przez nas problem, mimo że - jak wspomniałam powołując się na słowa Karin Norman - zawsze jesteśmy gdzieś umiejscowieni.

Zbierany przez nas materiał $\mathrm{z}$ terenu może zatem pochodzić z czasu rzeczywistego przebywania tam oraz ,post-terenowego” bycia tu. Pojawia się pytanie, czy i w jaki sposób możemy takie dane wykorzystać. Wszak jedną z podstawowych dyrektyw etycznych w antropologii jest świadoma zgoda uczestników badań na przeprowadzenie z nimi rozmów lub wywiadów (zob. choćby podręcznik Martyna Ha m m e r s le y a i Paula A t k in s o n a (2000: 269)). Ponadto - w jaki sposób można wykorzystać takie dane? Jeśli założymy, że nie będziemy używać ich wprost, ponieważ z różnych powodów byłoby to nieetyczne, to przecież mamy te dane w głowie (a przecież headnotes są równie ważne jak fieldnotes!) i one znacząco wpływają na nasz dalszy proces badawczy.

Dodatkowym kłopotem jest to, że nie tylko nasz teren i nasi rozmówcy się zmieniają, ale również my sami się zmieniamy - starzejemy się, zmienia się nasz status na uniwersytecie bądź sytuacja życiowa. Poniżej postaram się przedstawić mnie samą $\mathrm{w}$ terenie $\mathrm{w}$ różnych odsłonach zgodnie $\mathrm{z}$ dwoma założeniami Kirsten Hastrup: po pierwsze, że „badania terenowe należą do dwóch obszarów - autobiografii i antropologii. W związku z tym łączą one ważne doświadczenie osobiste z ogólnym zakresem wiedzy" (H a s tr u p 1992: 118), po drugie, że teren zawiera w sobie etnografkę (H a stru p 2008: 70).

\section{RÓŻNE „JA”: POLKA, CHRZEŚCIJANKA, KOBIETA, PANNA, MĘŻATKA, MATKA}

Podczas kilkuletnich badań terenowych w zachodniej Macedonii zobaczyłam i doświadczyłam siebie w terenie jako panna, potem mężatka w ciąży i matka z dzieckiem. Miałam również niezmienny status Polki (obcokrajowca) oraz chrześcijanki (względem Muzułmanów), a względem prawosławnych - katoliczki. Role te wiązały się z różnorodnością dostępu do rozmówców i tematów, które de facto były mi w pewnym sensie narzucane. Ta ostatnia kwestia jest szeroko opisywana $\mathrm{w}$ literaturze $\mathrm{i}$ wiąże się z pojęciem etnograficznego autorytetu oraz autorstwa tekstu (zob. klasyczny tekst Jamesa C 1 i f f o r d a (2000)).

Po raz pierwszy do zachodniej Macedonii przyjechałam z grupą studentów, aby prowadzić badania na temat relacji etnicznych i społecznych wśród sąsiadują- 
cych ze sobą Turków, Torbeszów, Albańczyków i Macedończyków oraz - biorąc pod uwagę kryterium religijne - prawosławnych i Muzułmanów³ ${ }^{3}$ Byliśmy grupą młodych (21-29 lat) osób, w przeważającej mierze kobiet. Nikt z nas nie był wtedy w związku małżeńskim. Problemy, z którymi zetknęliśmy się w terenie, dotyczyły pewnych wspólnych elementów naszych biografii, które wyróżniały nas z miejscowego otoczenia. A były to: narodowość, język i religia. Jako posługujący się językiem macedońskim chrześcijanie byliśmy niejako „bliżsi” Macedończykom prawosławnym niż np. muzułmanom-Albańczykom). Stawiało nas to niejednokrotnie przed problemem pokazania, że nie jesteśmy po niczyjej stronie (mam tu na uwadze zwłaszcza relacje macedońsko-albańskie, ale też prawosławno-muzułmańskie). Prawosławni Macedończycy podejrzliwie patrzyli na nasze zainteresowanie islamem i innymi niż Macedończycy wspólnotami ${ }^{4}$. Gdy przyjechałam do Macedonii już po zakończeniu badań ze studentami, mieszkałam wraz z koleżanką doktorantką w klasztorze. Któregoś dnia kupiłam książkę na temat różnic między chrześcijaństwem i islamem i pokazałam ją jednej z sióstr. O ile ona sama w sposób bardzo taktowny oceniła ją negatywnie, o tyle inne siostry chciały tę publikację zniszczyć lub wyrzucićs. Okazało się również, że wiele sióstr ma bardzo negatywny stosunek do islamu i muzułmanów w ogóle, mimo że klasztor położony jest w otoczeniu niemal wyłącznie muzułmańskich miejscowości.

Kolejny problem w prowadzeniu badań w zachodniej Macedonii sprawiało pochodzenie z Polski, a zwłaszcza bycie kobietami z Polski. Region, w którym przebywaliśmy, to tzw. peczalbarski kraj, a więc obszar, w którym głównym (lub z jednym z głównych) sposobów zarobkowania jest migracja zarobkowa (peczalba lub gurbet), w tym przypadku do Włoch. Wielu mieszkańców miało więc kontakt z osobami z Polski mieszkającymi we Włoszech. A że są to przede wszystkim kobiety, często mające opinię swobodnych seksualnie, ta opinia przeniosła się również na nas. Zwłaszcza że nasze zachowanie odbiegało od zachowania miejscowych dziewcząt. $Z$ racji wykonywanej pracy często pojawiałyśmy się na ulicy lub w innych miejscach publicznych, nie zasłaniałyśmy głów. Mimo że ubierałyśmy się skromnie i nie wychodziłyśmy same do kawiarń, szybko stałyśmy się obiektem zainteresowania lokalnych kawalerów. Oni też - chłopcy w wieku ok. 20-25 lat - stali się naszymi głównymi i jedynymi dostępnymi rozmówcami.

3 Badania te odbywały się w ramach realizacji grantu finansowanego przez MNiSW „Macedończycy i Albańczycy - sąsiedztwo w obliczu konfliktu”, nr N10901532/0635.

4 Termin „wspólnota” w znaczeniu grupy etnicznej lub narodowej zastąpił w oficjalnym dyskursie publicznym w Macedonii określenie „naród” i „,narodowość”. Pojawił się on w Ramowym Porozumieniu z Ochrydy (z 13 sierpnia 2001 r.) po zakończeniu zbrojnego konfliktu macedońsko-albańskiego w roku 2001 i został podpisany przez obie strony.

5 Faktem jest, że książka mimo bardzo neutralnego tytułu, Chrześcijaństwo i islam według Biblii i Koranu (Hristijanstvoto i islamot spored Biblijata i Kuranot) okazała się stronnicza i krzywdząca dla chrześcijan. 
Ja, z racji funkcji (,profesorka”) miałam też okazję rozmawiać z mężczyznami starszymi od siebie i żonatymi, ale oni również traktowali mnie raczej jak potencjalną kochankę niż partnerkę do rozmowy.

Wiele zmieniło się, gdy przyjechałam w teren po skończonych badaniach ze studentami, będąc już mężatką w widocznej ciąży. Mieszkałam wtedy, jak wspomniałam, w prawosławnym klasztorze. Niemniej jednak pojawiłam się kilka razy we wsiach, w których przebywałam ze studentami. Pomimo że od razu dotarła do mnie plotka, że ojcem dziecka jest jeden z miejscowych chłopaków, miałam znacznie większy dostęp do kobiet, które próbowały odgadnąć płeć dziecka i udzielały mi rozmaitych porad. Adorujący mnie rok wcześniej 50-letni dyrektor szkoły, zaczął traktować o wiele bardziej „,poważnie” i dopiero wtedy udało mi się $\mathrm{z}$ nim porozmawiać na interesujące tematy zawodowe.

Kolejne badania, związane z nowym tematem, przeprowadziłam w następnym roku, gdy oprócz asystentki towarzyszył mi 10-miesięczny synek. Zamieszkaliśmy w małym domku wynajmowanym nam przez przedsiębiorczą starszą Torbeszkę, Fatmę, w mieszanej muzułmańsko-prawosławnej wsi w południowo-zachodniej Macedonii. Była ona głową rodziny, wdową i matką czterech synów i jednej córki, teściową czterech synowych i jednego zięcia oraz babcią ośmiorga wnucząt. Na co dzień Fatma mieszka z synowymi, jednym synem i sześciorgiem wnucząt. Trzej synowie mieszkają bowiem na peczalbie - w Słowenii lub we Włoszech. Jeden z nich podczas naszego pobytu przyjechał na krótko z Włoch. Poza nim niemal nie miałyśmy męskich rozmówców. Zaborcza Fatma niechętnie zgadzała się również, abyśmy odwiedzały kogoś innego poza jej rodziną. Wyjątkiem była prawosławna Katerina, zaprzyjaźniona sąsiadka, matka dwóch par bliźniąt, żona mężczyzny pracującego na co dzień w Słowenii. Tematy, które wtedy poruszałyśmy, w zasadzie narzucał mój mały synek. Podczas gdy wymieniałyśmy z rozmówczyniami doświadczenia związane z zajmowaniem się małym dzieckiem, życie na peczalbie, a raczej życie bez mężczyzn na co dzień było niejako dodatkowym, choć bardzo ważnym tematem. Problem, jaki tutaj się pojawił, dotyczył mojej odpowiedzialności jako żony i matki, a w zasadzie jej braku. Musiałam zmierzyć się z tym, że zostałam włączona w system wartości moich rozmówczyń, które nie podróżują bez męża, a tym bardziej z niemowlęciem. Co więcej, nie nawiązują kontaktów z obcymi ludźmi bez zgody męża. Dlatego też nie garnęłam się do rozmów z mężczyznami. Tym razem dla młodych chłopaków jako matka z dzieckiem nie byłam żadną atrakcją, a nawet nie miałam możliwości wychodzenia wieczorami, aby ich spotykać. Żonatych i starszych mężczyzn albo nie było we wsi, albo obawiali się obmowy i oskarżeń o zbyt bliskie kontakty z młodą mężatką.

\footnotetext{
${ }^{6}$ Wyraz ten określa w języku macedońskim każdego nauczyciela.

7 Wszystkie imiona rozmówców zostały zmienione.
} 
Ostatnie badania, na które pojechałam z asystentką, zostały przeprowadzone w jednej z miejscowości w północnych Włoszech. Tutaj sytuacja była diametralnie różna. Po pierwsze, miałyśmy „odźwierną”, kobietę pracującą wśród Macedończyków (w większości Torbeszów), a po drugie (co wynika z pierwszego), naszymi rozmówcami były przede wszystkim kobiety. Natasza pracuje w charakterze mediatorki kulturowej, pomagając migrantom jako tłumaczka w szkołach i szpitalach. Organizuje również dla nich kurs języka włoskiego. W związku z tym, że problemy językowe mają przede wszystkim kobiety, które bardzo rzadko pracują zarobkowo, Natasza zwykle pracuje z nimi. Badania te były dość specyficzne, ponieważ w zasadzie nie udało się przeprowadzić oficjalnych, nagrywanych wywiadów. Były to przede wszystkim luźne, nieformalne rozmowy przy kawie (nie włoskiej, ale po turecku!) i ciasteczkach, albowiem i temat był specyficzny życie codzienne migrantów. Rozmawiałyśmy więc o zwykłych problemach, które jednak dały mi ogromną wiedzę na temat zaangażowania lub raczej jego braku w kraju przyjmującym. Migrantki żyją bardzo podobnie, jak w Macedonii - zajmują się domem i dziećmi. Tutaj mają jednak mniej obowiązków i problemów niż w kraju pochodzenia: nie muszą pracować na roli ani mieszkać pod wspólnym dachem z często niechętną teściową. Mają zatem czas na codzienne odwiedziny sąsiadek i oglądanie filmów lub płyt z nagranymi weselami, z Macedonii. Nie zamierzają również iść do pracy - nie tylko dlatego, że ich mężowie mogliby czuć się o nie zazdrośni lub chcą udowodnić, że sprawdzają się w roli żywicieli rodziny - ale również dlatego, że musiałyby zmienić swój codzienny tryb życia. Jak powiedziała jedna z rozmówczyń: „Nawet jak już szukają pracy, to modlą się do Boga, żeby jej nie dostać". Z nielicznymi mężczyznami, z którymi udało się nawiązać dialog, rozmowy (tu nawet można użyć słowa „wywiad”) były zupełnie inne. Okazuje się, że wielu z nich chętnie rozmawia na temat swojego zaangażowania politycznego oraz praktyki religijnej. Ponadto są oni tymi, którzy jako pierwsi przyjechali do Włoch, a potem przywieźli rodzinę - prezentują więc siebie jako tych, którzy musieli zmagać się w pierwszych latach pobytu za granicą $\mathrm{z}$ trudnościami w znalezieniu pracy lub nielegalnością pobytu. Rozmowy z mężczyznami nie były już jednak obarczone żadnymi podtekstami seksualnymi. Byłam oficjalną przedstawicielką uniwersytetu z Polski, znajomą mającej autorytet Nataszy oraz do tych mężczyzn docierałam poprzez ich żony.

Wszystkie powyżej opisane sytuacje z ,terenu" w połączeniu ze zmianą mojego statusu wynikającego ze zmiany stanu cywilnego, pozycji na uniwersytecie i wieku, pokazują, że po pierwsze, nie zawsze byłam w stanie prowadzić badania na temat, który sobie wcześniej przygotowałam - on ewoluował bądź wręcz był narzucany mi przez rozmówców lub przez sytuację, w jakiej się znajdowałam. Po drugie, nie do końca byłam w stanie moderować prowadzone dyskusje, a tym bardziej świadomie dobierać rozmówców.

Nasuwa się co najmniej kilka wniosków. Jednym z nich jest spostrzeżenie, że nasza biografia (positionality) niejako wymusza dobór rozmówców oraz 
tematów, którymi się zajmujemy. Trafnie to opisała Diane C. Freedman, która w ciągu roku przyjechała $\mathrm{w}$ teren $\mathrm{z}$ mężem, potem jako młoda wdowa, wreszcie po żałobie jako wolna kobieta (F r e e d m a n 1986). Podobnie Margaret K e n n a (1992) pisze o swoich długotrwałych badaniach w Grecji i o tym, jak jej status na uniwersytecie oraz wyjście za mąż i urodzenie dziecka wpłynęły na postrzeganie jej przez rozmówców. W moim przypadku również to, kim jestem zdeterminowało i nadal determinuje badania.

Pojawia się jeszcze pytanie, na ile my samy możemy (mamy prawo?) kształtować siebie samych. Jak zauważa Gary Alan Fine, jednym z kłamstw etnografów jest udawanie osób przyzwoitych (F i n e 2010: 100-102). Z pewnością można by powiedzieć, że nie wynika to jedynie z chęci kłamstwa, ale również z szacunku względem ludzi, którzy poświęcają nam swój czas. Inny problem, może znacznie poważniejszy, to ujawnianie bądź nie własnych poglądów i przekonań. Chodzi przede wszystkim o poglądy polityczne i przekonania religijne. W przypadku badań na terenie wieloetnicznym i konfliktogennym znacząca jest ugruntowana postawa względem bieżącej polityki państwa oraz lokalnej. Jak wspomniałam wyżej, posługiwanie się językiem macedońskim stawiało nas w pozycji bliższej Macedończykom niż Albańczykom lub Turkom, z kolei pochodzenie z Polski (kraju chrześcijańskiego) zbliżało nas do prawosławnych. Nie oznacza to bynajmniej, że Albańczycy nie chcieli z nami rozmawiać, ale wręcz przeciwnie - Macedończycy prawosławni byli zaniepokojeni naszym zainteresowaniem Sziptarami ${ }^{8}$ i islamem. Niejednokrotnie Macedończycy wymagali wręcz od nas jasnego opowiedzenia się po ich stronie, podczas gdy Albańczycy oczekiwali, że możemy się zaangażować na ich rzecz i mówić ich głosem (jako obiektywni obcokrajowcy). Podobnie jest zresztą z opisywanymi poniżej Torbeszami, którzy już sam fakt zainteresowania nimi postrzegają jako chęć niesienia im pomocy. Najprostszym wyjściem byłoby unikanie otwartych rozmów o polityce, ale jeśli jest to jeden z ważnych tematów badań, uniknąć się go nie da. Należy więc zręcznie lawirować, unikać bezpośrednich odpowiedzi i być może nawet kłamać (a przynajmniej milcząco przytakiwać). Drugą kwestią jest religia. O ile wpisujemy się w narzucony nam przez rozmówców schemat, tj. będąc z Polski jesteśmy katolikami, problemu nie ma. Możemy być, co najwyżej, narażeni na próby nawrócenia lub nawet na wyśmianie własnych obrzędów i wierzeń ${ }^{9}$. Gorzej jednak, gdy jesteśmy całkiem innego wyznania lub ateistami. Wtedy jedyne, co pozostaje, to unikanie otwartego mówienia o własnej religijności lub milczące przyjęcie tego, co narzucili nam rozmówcy. Jest jednak zawsze bardzo płynna granica pomiędzy unikaniem niepotrzebnych konfliktów lub prowokacji oraz zwykłym kłamstwem.

8 Tu: obraźliwe określenie Albańczyków.

9 Np. od macedońskiego prawosławnego duchownego miałam raz okazję usłyszeć, że katolicy zamiast w Boga, wierzą w papieża. 


\section{TORBESZE W DYSKURSIE PUBLICZNYM I NAUKOWYM W MACEDONII}

Macedońscy Muzułmanie, zwani inaczej macedońskojęzycznymi Muzułmanami, zislamizowanymi Macedończykami lub Torbeszami są wspólnotą posługującą się językiem macedońskim i wyznającą islam. Czasem traktuje się ich łącznie z muzułmanami z Bośni - Bosznjakami, Goranami z pogranicza Macedonii, Serbii i Kosowa, oraz z Pomakami z Bułgarii. Tym, co łączy wszystkie grupy, jest posługiwanie się którymś z języków bądź dialektów południowosłowiańskich oraz wyznawana religia. Ponadto łączy je również oficjalna wykładnia, że są oni potomkami chrześcijan, którzy z różnych powodów przeszli na islam podczas panowania Imperium Osmańskiego na Bałkanach. Określenie Torbesz, podobnie zresztą jak Pomak, często bywa odbierane przez nich samych jako obraźliwe. Wynika to z ludowych etymologii tych nazw, które wskazują na sposób przejścia na islam - pod przymusem (Pomacy to ci, którzy zostali „umęczeni”, bułg. măka to męka) lub ze względów ekonomicznych (Torbesze to ci, którzy „sprzedali swoją wiarę za torbę mąki lub sera"). Pozostaję jednak w niniejszym tekście przy terminach Torbesz i macedońskojęzyczny Muzułmanin, ponieważ to pierwsze określenie funkcjonuje wśród orędowników uznania tej wspólnoty za odrębną grupę etniczną, a to drugie jest najbardziej neutralne (w dyskursie publicznym przeważa termin „Macedończyk Muzułmanin”, Makedonec Musliman). Problem nie dotyczy jednak tylko nazwy, ale przede wszystkim różnorodnych identyfikacji samych Torbeszów, a także postrzegania ich zarówno przez sąsiadów, jak i przez struktury państwowe.

Torbesze zamieszkują przede wszystkim zachodnią Macedonię, gdzie znaczącą grupę stanowią Albańczycy (w wielu miejscowościach są oni poza tym większością). Od jakiegoś czasu mówi się o albanizacji macedońskojęzycznych Muzułmanów, choć np. Aneta Svetieva zauważa, że proces ten miał już miejsce w początkach XX w., a zwłaszcza podczas II wojny światowej, kiedy podczas okupacji tych terenów przez Włochy (czy w rzeczywistości przez Albanię) narzucono macedońskim Muzułmanom przymusową edukację w języku albańskim, a także zmieniono im imiona i nazwiska (S v et i e v a 2003: 53). Obecnie język albański dominuje w religii, mianowicie jest de facto głównym językiem Muzułmańskiej Wspólnoty Wyznaniowej (Verska Islamska Zaednica), a po albańsku wydawana jest większość książek dotyczących islamu.

Podczas moich badań spotkałam się przede wszystkim z turcyzacją Torbeszów, choć poznałam również takie osoby, które deklarowały swój związek z narodem albańskim, ale podkreślały, że robią to ze względów praktycznych. Mianowicie, łatwiej jest im się odnaleźć wśród albańskiej większości, np. znaleźć pracę. Dlatego osoby te mówiły o sobie, że „tylko w spisie podają, że są Albańczykami" (samo se pišuvat Albanci). 
W jednej z gmin zachodniej Macedonii (Centar Żupa) większość mieszkańców deklaruje się jako Turcy. I rzeczywiście, w części gminy zwanej Górna Żupa (Gorna Župa), można spotkać charakterystycznie ubrane kobiety, a na ulicach tamtych wiosek słychać przede wszystkim turecki. Co więcej, znaczna część kobiet i niechodzących jeszcze do szkoły dzieci bardzo słabo zna język macedoński, ponieważ językiem ich codziennej komunikacji jest turecki. Oglądają telewizję nadawaną z Turcji, zrzeszają się w stowarzyszeniach promujących turecką kulturę i folklor. Poza tym z jednej z tamtejszych wsi, Kodżadżik (tur. Kocacik, mac. Kodžadžik), pochodził ojciec samego Mustafy Kemala Atatürka. Niemniej jednak już w części gminy zwanej Dolna Župa takiego związku z kulturą turecką nie ma. Co więcej, język turecki wcale nie jest tu powszechny. Naucza się go w miejscowej szkole podstawowej (na równi z macedońskim i albańskim), część uczniów uczęszcza dalej do tureckojęzycznej szkoły w Gostiwarze. Jednak sporo młodych, a większość ludzi w średnim wieku i starszych tureckiego nie zna. Nie przeszkadza to im deklarować się jako Turcy, a dokładniej „Turcy, którzy zapomnieli swojego języka". Tłumaczą to w ten sposób, że są potomkami Turków osmańskich, którzy przez wieki żyjąc poza ojczyzną nie mieli możliwości przekazywania swojego języka z pokolenia na pokolenie.

W dalszym ciągu część Torbeszów deklaruje się jako Macedończycy bądź macedońscy Muzułmanie, wskazując na przynależność do narodu macedońskiego i wskazując wspólne cechy: język oraz elementy obrzędowości. Orędownikiem takiej identyfikacji był Nijazi Limanoski - macedoński Muzułmanin oraz etnolog, twórca Kulturowo-Naukowego Manifestu Macedońskich Muzułmanów (Kulturno-Nauč Manifest na Makedoncite Muslimani) „mającego na celu badanie etnohistorycznej przeszłości, źródłowych etnospołecznych wartości i cech (język macedoński, folklor, obyczaje, kultura zarówno materialna, jak i duchowa) oraz rozwijanie poczucia przynależności narodowej wśród Macedońskich Muzułmanów jako Macedończyków, jako nierozerwalnej części całości narodu macedońskiego" (Li m a n o s k i 1993: 369). Niektórzy z kolei kładą nacisk na wyznanie, deklarując, że są po prostu Muzułmanami - nie tylko w sensie religijnym, ale i narodowym. Nawiązują tu do wprowadzonej w socjalistycznej Jugosławii kategorii narodowej „Muzułmanin” na określenie przede wszystkim mieszkańców Bośni i Hercegowiny oraz Sandżaku ${ }^{10}$.

Ostatnią grupę stanowią ci, którzy uważają, że są odrębną grupą etniczną. Sami się określają mianem Torbesze w sposób neutralny i uważają się za potomków bogomiłów ${ }^{11}$ - synkretycznej grupy religijnej łączącej chrześcijaństwo z zaratustrianizmem, powstałej $\mathrm{w} X \mathrm{~W}$., która przyjęła islam dobrowolnie i niejako

10 W 1961 r. Muzułmanie zostali uznani za narodowość, a 10 lat później za naród (B r i n g a 1995: 27).

11 Etymologia wyrazu Torbesz również wiąże się tu z ,torbą”, ale wypełnioną świętymi księgami noszonymi przez bogomilskich misjonarzy. 
naturalnie - ze względu na podobieństwo przekonań i praktyk religijnych. Od kilku lat powstają stowarzyszenia promoujące odrębność kulturową Torbeszów, a także - choć nie oficjalnie - promuje ją powstała w 2005 r. Partia na rzecz Przyszłości Europy (Partia za Evropska Idnina) na czele z Fijatem Canoskim, deklarującym się jako Torbesz (w ten sposób on oraz kilku innych członków partii określają się na stronie internetowej www.pei.org.mk, wpisując w rubryce „narodowość" Torbesz) $)^{12}$.

A zatem, jak widać z powyższych przykładów, macedońscy Muzułmanie są jednomyślni w kwestii własnej przynależności. Sara Arko dodaje zresztą jeszcze jeden fakt, który znacząco wpływa na ich indywidualne i zbiorowe tożsamości, mianowicie silny związek z tradycyjnym sposobem zarobkowania - migracją ekonomiczną, peczalba (A r k o 2009). Ponadto Torbesze są obiektem propagandy ze strony kilku wspólnot narodowych: Macedończyków (bo ich językiem jest macedoński) oraz Turków i Albańczyków (bo są muzułmanami).

Dyskurs ten w znacznej mierze przekłada się na naukę. W Macedonii badacze macedońscy zajmują się przede wszystkim własną grupą narodową - włączając w to „Macedończyków, których wyznaniem jest islam”, czyli Torbeszami. Podobnie jak Albańczyków badają Albańczycy, a Turków Turcy. Wyjątkiem są badania obcokrajowców, a zwłaszcza pochodzących spoza Bałkanów, którzy niejednokrotnie zajmują się innymi niż macedońska wspólnotami.

Macedońscy badacze niejako a priori uznają Torbeszów (zresztą w zasadzie w ogóle lub prawie w ogóle nie używa się tej nazwy) za przedstawicieli narodu macedońskiego, a wyznanie thumaczone jest islamizacją (przymusową) w czasach Imperium Osmańskiego; stąd też jedno z bardziej rozpowszechnionych określeń: zislamizowani Macedończycy (Islamizirani Makedonci; np. S v e ti e v a 2003).

Korzystając z tekstów i konsultacji z macedońskimi naukowcami (a oczywiste jest, że należy to robić), łatwo wpaść w pułapkę ideologizowania swojego tematu badań z jednej strony, a z drugiej - popaść w konflikt z lokalnymi badaczami (co jest ważne, bo często się z nimi współpracuje w terenie). Ja osobiście $\mathrm{w}$ taki konflikt nie popadłam, ale wiele razy byłam strofowana za zbyt subiektywne podejście do tematu (czyli de facto oddawanie głosu rozmówcom!) oraz pouczana, w jaki sposób powinno się prowadzić badania. Mianowicie, ja jako osoba z zewnątrz (cudzoziemka) nie mam możliwości poznania „prawdziwej” sytuacji w Macedonii, więc muszę zdać się na wiedzę i doświadczenie badaczy lokalnych. Bardzo wymowny przykład takiego podejścia spotkał Keitha B r o w n a (2003), autora książki dotyczącej m.in. powstania w Kruszewie The Past in Question: Modern Macedonia and the Uncertainties of Nation. Miałam okazję być na prezentacji macedońskiego tumaczenia tej publikacji - doszło do ostrej wymiany zdań pomiędzy Keithem i macedońskimi historykami (potem już tylko

12 Więcej na temat różnorodności i płynności identyfikacji macedońskojęzycznych Muzułmanów: B i e le n in-L e n c z o w sk a 2008. 
historycy się między sobą kłócili). Okazało się, że nie łatwo jest pisać o trudnej historii i wytykać błędy przedstawicielom tak niestabilnego i młodego państwa, jakim jest Macedonia. Podobnie - jak w moim przypadku - nie wolno wypowiadać się na temat kwestii etnicznych i pokazywać, że nie ma czarno-białych schematów, tj. że Macedończycy są niewinni i pokrzywdzeni, a całe zło przychodzi ze strony Albańczyków, a w dalszej kolejności od Greków, Bułgarów, Serbów i Turków. O tym wszystkim mogą mówić i pisać sami Macedończycy, którzy jako jedyni - wedle ich własnego zdania - są w stanie dogłębnie poznać sytuację w kraju. Wynika to z ich pewnej, niezdefiniowanej kompetencji, a także zażyłości kulturowej, posługując się określeniem Michaela Herzfelda, czyli zespołu wspólnych praktyk i zachowań. Badacz ten obrazowo pokazał funkcjonowanie nazwy „barbarzyńca” wśród Greków. Podczas gdy sami Grecy mogą tak określić niestosownie zachowującą się osobę, nikt poza nimi nie może tego zrobić, bo przecież „barbarzyńskość” to cecha Turków (H e r z feld 2007: 95). Dlatego, korzystając ze źródeł naukowych, a tym bardziej pozanaukowych, jak prasa lub wypowiedzi polityków różnych opcji, musimy mieć świadomość, że zwykle są one jednostronne. Stworzenie jakiegoś wyważonego opisu (ale czy antropolodzy muszą być „wyważeni”?) jest bardzo trudne, zwłaszcza gdy ma się do czynienia z badaniami w kraju o bardzo niestabilnej sytuacji politycznej i gospodarczej. Przykład badanych przeze mnie macedońskojęzycznych Muzułmanów jest znaczący, ponieważ w oficjalnym dyskursie naukowym uważa się ich za etnicznych Macedończyków, którzy przeszli na islam w czasach Imperium Osmańskiego. A zatem nie dopuszcza się innej interpretacji ich tożsamości, co oznacza, że ich samych nie dopuszcza się do głosu.

Jak zostało wspomniane wyżej, podczas badań prowadzonych wśród grupy mniejszościowej na interesujący nas temat, bardzo często stajemy przed kłopotliwymi pytaniami rozmówców o to, po której stronie się opowiadamy oraz przed prośbami o działanie, tj. publiczne wypowiedzi na ich rzecz. W przypadku moich badań były to takie sytuacje, jak zaproszenie do radia albańskiego, aby wypowiedzieć się na temat sytuacji Albańczyków w Macedonii lub prośba o zostanie członkiem honorowym pewnego torbeszkiego stowarzyszenia, a także - zaproszenie do zostania członkinią partii PEI. Członkinią stowarzyszenia zostałam, ale do partii już się nie zapisałam, nie poszłam również do radia. Swoje zaangażowanie wyrażam w publikacjach oraz referatach konferencyjnych, a także w mniej lub bardziej nieformalnych rozmowach $\mathrm{z}$ naukowcami z Macedonii. Mam nadzieję jednak, że badania moje będą mogły dotrzeć do szerszego grona niż tylko naukowe.

Kwestia zaangażowania się w ważne problemy społeczne i udział w debacie publicznej na ich temat są $\mathrm{w}$ antropologii osobnymi problemami. Nasza dyscyplina ma narzędzia, za pomocą których w taką debatę może się włączyć. Poznajemy bowiem oddolne praktyki i strategie ludzi, z którymi pracujemy. Z mojej perspektywy i w myśl mojego pojmowania roli antropologii, nie pytam, czy się angażować, ale w jaki sposób. W przypadku badań, takich jak moje, już sam opis sytuacji 
Torbeszów pozwala na oddanie głosu im samym i pokazanie, że należy wziąć pod uwagę wszystkie rodzaje i strategie ich identyfikacji. Są one często jednostkowe i wynikające z różnych motywów. Opowiadam się nie tyle za którąś konkretną grupą narodową lub etniczną, ale za prawem każdej z nich do publicznego wyrażania swoich opinii. A przede wszystkim opowiadam się za prawem jednostek do ich własnych deklaracji. Dlatego też popieram starania macedońskojęzycznych Muzułmanów o uznanie ich za odrębną wspólnotę, ale też nie potępiam tych z nich, którzy wybrali opcję proturecką lub proalbańską. Łatwo jest bowiem zostać aktywistą, trudniej być zaangażowanym naukowcem. To jest jednak zupełnie inny temat.

\section{KONKLUZJE I NOWE PYTANIA}

Przedstawione w niniejszym artykule zagadnienia i problemy w znacznej mierze zostały już przez antropologów opisane. Uważam jednak, że zarówno pozycja badacza $\mathrm{w}$ terenie, jak i samo pojęcie terenu lub badań terenowych są szczególnie istotne w zmieniających się realiach naszego świata. Należy zatem o nich mówić i brać je pod uwagę w całym procesie tworzenia i prezentowania wiedzy. Zwłaszcza że dotyczą one każdego z nas, bowiem można je spotkać przy okazji analizy rozmaitych tematów i prowadzenia badań w różnych regionach.

Istotną kwestią jest także lokalna wiedza naukowa na interesujący nas temat. W przypadku takich miejsc, jak kraje Półwyspu Bałkańskiego, mamy do czynienia $\mathrm{z}$ wieloma sytuacjami konfliktowymi oraz historycznymi resentymentami. Macedonia jest krajem wieloetnicznym, borykającym się z rozmaitymi problemami natury politycznej i ekonomicznej oraz roszczeniami w stosunku do jej kultury, dziedzictwa i terytorium ze strony wszystkich sąsiadów. Niemniej jednak wszystkie wspólnoty etniczne i narodowe w Macedonii mają (przynajmniej w teorii) zapewnione równe prawa. Nie dziwi więc fakt, że tak niespójna w kwestii własnej identyfikacji grupa, jak macedońskojęzyczni Muzułmanie, staje się obiektem propagandy z każdej strony. Wszystkie wspólnoty chcą ją bowiem pozyskać dla siebie - przede wszystkim w spisach, przez co można udowodnić większą liczebność, a tym samym zyskać więcej możliwości np. zatrudnienia w administracji publicznej lub wprowadzić dodatkowe przywileje $\mathrm{w}$ gminach wieloetnicznych (jak np. media, edukacja w danym języku). Problem jest jednak w tym, że albańską i turecką propagandę zauważają Macedończycy, nie widząc, że i oni sami ją tworzą zarówno na poziomie polityki (co jest zresztą normalne i zrozumiałe), jak i nauki. Dlatego też, z nielicznymi wyjątkami ${ }^{13}$, trudno znaleźć tekst, który pokazywałby Torbeszów od strony ich własnych deklaracji, a przede wszystkim

13 Takim wyjątkiem jest artykuł Ljupča R i s t e s k i e g o (2009), Dynamika tożsamości Torbeszów w Republice Macedonii. 
motywów tych różnych, często zmiennych, deklaracji. Wreszcie, trudno jest nie opowiedzieć się po którejś stronie. Na szczęście antropologia nie jest i wcale nie musi być obiektywna.

\section{BIBLIOGRAFIA}

A m it Vered (ed.) (2000), Constructing the Field. Ethnographic Fieldwork in the Contemporary World, Routlege, London.

A r k о Sara [Арко Cара] (2009), Јас (не) сум Торбеш. Етничноста во едно западномакедонско село - конструкции и политицизации, „Етнолог/Ethnologist”, Нo 12-13, s. 187-208.

B i e len in-L e n c zow s k Karolina (2008), The Construction of Identity in a Multi-Ethnic Community: A Case Study on the Torbeši of Centar Župa Commune, Western Macedonia (FYROM)”, „Ethnologia Balkanica”, Vol. 12, s. 167-181.

B r in g a Tone (1995), Being Muslim the Bosnian Way. Identity and Community in a Central Bosnian Village, Princeton University Press, New Jersey.

B r o w n Keith (2003), The Past in Question: Modern Macedonia and the Uncertainties of Nation, Princeton University Press, New Jersey.

C a p u to Virginia (2000), At "home" and "away": Reconfiguring the Field for Late Twentieth-century Anthropology, [w:] A. Ver e d (ed.), Constructing the Field. Ethnographic Fieldwork in the Contemporary World, Routlege, London, s. 19-31.

C 1 ifford James (2000), Kłopoty z kultura. Dwudziestowieczna etnografia, literatura i sztuka, Wydawnictwo KR, Warszawa.

F in e Gary Alan (2010), Dziesięć kłamstw etnografii - dylematy etyczne w terenie, [w:] K. K a n i o w s k a, N. M o d n i c k a (red.), Etyczne problemy badań antropologicznych, ser. „,Lódzkie Studia Etnograficzne", vol. 49, Polskie Towarzystwo Ludoznawcze, Wrocław-Łódź, s. $87-112$.

F r e e d m a n Diane C. (1986), Wife, Widow, Woman: Roles of an Anthropologist in a Transylvanian Village, [w:] Women in the Field. Anthropological Experiences, P. Golde (ed.), University of California Press, Berkeley, s. 333-357.

G u p t a Akhil, F e r g u s o n James (2004), Poza „kulturę”: przestrzeń, tożsamość i polityka różnicy, [w:] Badanie kultury. Elementy teorii antropologicznej. Kontynuacje, M. Kempny, E. Nowicka (red.), Wydawnictwo Naukowe PWN, Warszawa, s. 267-283.

Ha m m e r s l e y Martyn, A t kins on Paul (2000), Metody badań terenowych, Wydawnictwo Zysk i S-ka, Poznań.

H a s tr u p Kirsten (1987), Fieldwork among Friends: Ethnographic Exchange within the Northern Civilization, [w:] Anthropology at Home. ASA Monographs 25, A. Jackson (ed.), Tavistock Press, London, s. 94-108.

H a s tr u p Kirsten (1992), Writing Ethnography: State of the Art, [w:] Anthropology and Autobiography. ASA Monographs 29, H. Callaway, J. Okely (eds.), Routledge, London, s. 115-132.

H a s $\mathrm{r}$ u p Kirsten (2008), Droga do antropologii. Między doświadczeniem a teoria, Wydawnictwo Uniwersytetu Jagiellońskiego, Kraków.

H e r z f e 1 d Michael (2007), Zażyłość kulturowa. Poetyka społeczna w państwie narodowym, Wydawnictwo Uniwersytetu Jagiellońskiego, Kraków.

K a n i o w s k a Katarzyna (1999), Opis. Klucz do rozumienia kultury, ser. „Łódzkie Studia Etnograficzne", vol. 39, Polskie Towarzystwo Ludoznawcze, Łódź.

K e n n a Margaret (1992), Changing Places and Altered Perspectives: Research on a Greek Island in the 60s and in the 80s, [w:] Anthropology and Autobiography. ASA Monographs 29, H. Callaway, J. Okely (eds.), Routledge, London, s. 147-162. 
L i m a n o s k i Nijazi (1993), Islamization and Ethnic Changes in Macedonia, Kulturno-naučni manifestacii na Makedoncite muslimani, Skopje.

N o r m a n Karin (2000), Phoning the Field. Meanings of Place and Involvement in Fieldwork "at home", [w:] V. A m it (ed.), Constructing the Field. Ethnographic Fieldwork in the Contemporary World, Routlege, London, s. 120-146.

Notes and Queries on Anthropology (1912), B. F r e i r e - M a r r e c o, J. L. M y r e s (eds.), $4^{\text {th }}$ Ed., British Association for the Advancement of Science, London.

P in k Sarah (2000), "Informants" Who Come "Home", [w:] A. Ve red (ed.), Constructing the Field. Ethnographic Fieldwork in the Contemporary World, Routlege, London, s. 97-119.

R i s te s k i Ljupčo (2009), Dynamika tożsamości Torbeszów w Republice Macedonii, [w:] Sasiedztwo w obliczu konfliktu. Relacje społeczne i etniczne w zachodniej Macedonii - refleksje antropologiczne, K. Bielenin-Lenczowska (red.), Wydawnictwo DiG, Warszawa, s. 179-191.

S v e t i e v a Aneta (2003), Politicization of the ethnic identity of the Torbesh (the "Nashinci"). „Ethno-AnthropoZoom”, http://www.iea.pmf.ukim.edu.mk/EAZ/EAZ_03/EAZ_2004_PDF/ EAZ_2003_Ponizeni_Balkan_Ang.pdf, 18.06.2012.

\section{Karolina Bielenin-Lenczowska}

\section{DIFFICULT TOPICS, DIFFICULT FIELDWORK. ON MULTI-SITED ETHNOGRAPHY AMONG MACEDONIAN MUSLIMS (TORBESHI) IN MACEDONIA AND ITALY}

This paper is divided into two parts. In the first one, the author analyses the notion of a field and a fieldwork in a contemporary anthropology, giving examples from her own research. Her positionality not only gives various access to interlocutors but also defines or even determines her subjects of research. Conducting fieldwork in nowadays anthropology is strongly connected to using new technologies of communication. It causes numerous ethical and methodological dilemmas that should be taken into consideration during the whole process of getting and presenting knowledge.

In the second part of a text, a discourse on Torbeshi/Macedonian-speaking Muslims is analyzed. The author observes, this group is not unanimous in its self-identification. They declare to be Albanians, but also Turks, Macedonians, Muslims or separate ethnic group. Because of it, they are exposed to strong propaganda from Turkish, Albanian and Macedonian perspective. Author argues, this propaganda is also grown by Macedonian scholars for whom Torbeshi are Macedonians who converted into Islam during Ottoman Empire, while there are very few research on their own changing and fluid identification.

Keywords: field, fieldwork, anthropological ethics and methodology, Macedonian-speaking Muslims (Torbeshi), public discourse. 